\title{
Biocidal activity of partially purified fractions from methanolic extract of Garcinia kola (Heckel) seeds on bacterial isolates
}

\author{
AKINPELU DA ${ }^{1,2}$, ADEGBOYE $\mathrm{MF}^{2}, \mathrm{ADELOYE} \mathrm{OA}^{3} \mathrm{AND}^{*} \mathrm{OKOH} \mathrm{AI}^{1 *}$ \\ ${ }^{1}$ Applied and Environmental Microbiology Research Group (AEMREG), Department of Biochemistry and \\ Microbiology, University of Fort Hare, Alice, South Africa. \\ 2 Department of Microbiology, Obafemi Awolowo University, Ile Ife, Nigeria. \\ ${ }^{3}$ Department of Chemistry, University of Fort Hare, Alice, South Africa.
}

\begin{abstract}
The in vitro antibacterial activity of crude methanolic extract of the seeds of Garcinia kola was investigated. The extracts exhibited antibacterial activities with zones of inhibition ranging from $10 \mathrm{~mm}$ to $25 \mathrm{~mm}$. The minimum inhibitory concentration of the diethyl ether fraction was between 0.313 and $5.0 \mathrm{mg} / \mathrm{ml}$, while that of butanol fraction varied from 0.157 to $5.0 \mathrm{mg} / \mathrm{ml}$. The butanol fraction killed about $77 \%$ of Bacillus anthracis and $79 \%$ of Escherichia coli cells within $120 \mathrm{~min}$ at a concentration of $5.0 \mathrm{mg} / \mathrm{ml}$. Protein leakage from the $B$. anthracis and $E$. coli cells when exposed to the butanol and diethyl ether fractions was observed. We conclude that Garcinia kola seed extract has a broad spectrum antibacterial activity, with the butanol and diethyl ether fractions being bactericidal as exemplified by the killing rate and protein leakage regimes, which suggest cell membrane disruption as a mechanism of action of the extract.
\end{abstract}

Key terms: Garcinia kola, antimicrobial activity, MIC, killing rate, protein leakage.

\subsection{INTRODUCTION}

Medicinal plants have been used as folklore remedies over the years to treat, manage or control man's ailments. They contain large varieties of chemical substances that possess important therapeutic properties used in the treatment of these ailments. Also, the problem of bacterial resistance to commonly used antibiotics has necessitated the search for newer and alternative compounds for the treatment of drug resistant infections and the high cost of conventional drugs, particularly in resource poor communities of the African continent has led to the increased use of plants as an alternative for the treatment of infectious diseases (Sibanda and Okoh 2008a). Several findings on the chemotherapeutic potentials of plants have shown that they can be sources of antimicrobial compounds of value (Rabe and van Staden, 1997). A typical example of such plants is Garcinia kola.

Garcinia kola belongs to the family Guittiferae, and it is commonly referred to as bitter kola. The plant has the popular acronym "wonder plant" amongst the southwestern Nigerian people because every part of it has been found to be of medicinal importance (Dalziel, 1937). G. kola is used in folklore remedies for the treatment of ailments such as liver disorders, hepatitis, diarrhoea, laryngitis, bronchitis and gonorrhoea (Iwu, 1993; Adesina et al., 1995). The seed is masticatory and is also used to prevent and relieve colic, chest colds, and cough and can be used as well to treat headache (Ayensu, 1978). Iwu (1993) reported the use of this plant for the treatment of jaundice, high fever, purgative and chewing stick. The plant has also been

\footnotetext{
* Corresponding author (aokoh@ufh.ac.za; Tel/Fax: +27 40 6022354). Applied and Environmental Microbiology Research Group (AEMREG), Department of Biochemistry and Microbiology, University of Fort Hare, South Africa.
} 
found useful in the treatment of stomach ache and gastritis (Ajebesone and Aina, 2004).

Aqueous, ethanolic and petroleum ether extracts of the seeds have been observed to possess antibacterial properties (Ezeifeka et al., 2004), and Kolaviron, (a fraction of the deffated ethanol extract of the seed, containing Garcinia biflavonoid GB1, GB2 and kolaflavanone) has been reported to possess numerous therapeutic potentials (Farombi et al., 2002; Uko et al., 2001), along with such components as mixtures of phenolic compounds, biflavonoids, xanthones, benzophenones and related triterpenes (Han et al., 2005).

While numerous studies have been done on the antimicrobial potential of this plant, the overwhelming majority of the studies have concentrated on oral and respiratory tract pathogens (Akoachere et al., 2002; Ndukwe et al., 2005), thus underestimating the antimicrobial potential of the plant. As well, reports so far available on the antibacterial potential of the seed show that activity has been demonstrated for the aqueous, ethanolic, acetone and petroleum ether extracts of the seed (Sibanda and Okoh, 2008a,b; Ezeifeka et al., 2004). There are no documented reports in literature on the antimicrobial potential of the methanol extract of the seeds, or fractions thereof. In addition, while previous researchers have used MICs and MBCs as prediction tools for antimicrobial action of plant extracts, there are limitations in the use of such data since it does not consider time-related antimicrobial effects (Kiem and Schentag, 2006), such as killing rate. In this paper, we report the biocidal activity of crude methanolic extracts of the seeds of Garcinia kola, and use the killing rate of the extract and protein leakage from cells to predict their bactericidal efficiency.

\subsection{MATERIALS AND METHODS}

\subsubsection{Plant material}

Fresh seeds of G. kola were used in this work. The seeds were peeled and cut into pieces and later dried in a hot-air oven at 40
${ }^{\circ} \mathrm{C}$ to constant weight, powdered and kept in an air-tight container for further use.

\subsubsection{Preparation of the plant extract}

Exactly $850 \mathrm{~g}$ of the powdered seeds was soaked in a mixture of methanol and sterile distilled water in a 3:2 ratio for four days and later filtered to obtain the methanolic extract. The mixture was first concentrated in vacuo using a rotary evaporator to remove the methanol. The aqueous residue was then lyophilized to obtain a $7.2 \mathrm{~g}$ yield of a dark brown crude extract.

\subsubsection{Preparation of test microorganisms}

The following typed cultures and locally isolated (LIO) organisms obtained from the culture collection of the Microbiology Department, Obafemi Awolowo University, Ile Ife, Nigeria were used for this study:

Gram-positive: Bacillus subtilis (NCIB 3610), Staphylococcus aureus (NCIB 8588), Enterococcus faecalis (NCIB 775), Micrococcus luteus (NCIB 196), Bacillus cereus (NCIB 6349), Bacillus stearothermophillus (NCIB 8222), Bacillus polymyxa (LIO), Bacillus anthracis (LIO), Staphylococcus epidermidis (LIO), Clostridium sporogenes (NCIB 532), Corynebacterium pyogenes (LIO).

Gram-negative: Escherichia coli (NCIB 86), Pseudomonas aeruginosa (NCIB 950), Pseudomonas fluorescens (NCIB 3756), Klebsiella pneumoniae (NCIB 418).

For the experiment, the bacterial isolates were first subcultured in nutrient broth (Oxoid) and incubated at $37^{\circ} \mathrm{C}$ for $18 \mathrm{~h}$.

\subsubsection{Phytochemical assays}

A small portion of the dry extract was subjected to the phytochemical test using the methods of Trease and Evans (1983), and Harbourne (1983) to test for alkaloids, tannins, flavonoids, steroids, saponins, reducing sugars and cardiac glycoside.

\subsubsection{Test for alkaloids}

Exactly $0.5 \mathrm{~g}$ of the plant extract was dissolved in $5 \mathrm{ml}$ of $1 \% \mathrm{HCl}$ in a steam 
bath. One millilitre of the filtrate was treated with drops of Dragendorff's reagent. Turbidity or precipitation was taken as indicative of the presence of alkaloids.

\subsubsection{Test for tannins}

About $1 \mathrm{~g}$ of the extract was dissolved in 20 $\mathrm{ml}$ of distilled water and filtered. Two to three drops of $10 \%$ of $\mathrm{FeCl}_{3}$ was added to $2 \mathrm{ml}$ of the filtrate. The production of a blackish-blue or blackish-green colouration was indicative of tannins. To another $2 \mathrm{ml}$ of the filtrate was added $1 \mathrm{ml}$ of bromine water. A precipitate was taken as positive for tannins.

\subsubsection{Test for flavonoids}

About $0.2 \mathrm{~g}$ of the extract was dissolved in $2 \mathrm{ml}$ of methanol and heated. A chip of magnesium metal was added to the mixture, followed by the addition of a few drops of concentrated $\mathrm{HCl}$. The occurrence of a red or orange colouration was indicative of the flavonoids.

\subsubsection{Test for saponins}

Freshly prepared $7 \%$ blood agar medium was used and wells were made in it. The extract in methanol was applied with distilled water and methanol used separately as negative controls, while commercial saponin $(\mathrm{BDH})$ solution was used as positive control. The plates were incubated at $35^{\circ} \mathrm{C}$ for $6 \mathrm{~h}$. Complete haemolysis of the blood around the extract was indicative of saponins.

\subsubsection{Test for steroids}

The method of Igwe et al. (2007) was used to test for steroids. About $0.5 \mathrm{~g}$ of the extract was dissolved in $3 \mathrm{ml}$ of $\mathrm{CHCl}_{3}$ and filtered. To the filtrate was added concentrated $\mathrm{H}_{2} \mathrm{SO}_{4}$ to form a lower layer. A reddish brown colour was taken as positive for steroid ring.

\subsubsection{Test for cardiac glycoside}

About $0.5 \mathrm{~g}$ of the extract was dissolved in $2 \mathrm{ml}$ of glacial acetic acid containing 1 drop of $1 \% \mathrm{FeCl}_{3}$. This was underlaid with conc.
$\mathrm{H}_{2} \mathrm{SO}_{4}$. A brown ring obtained at the interface indicated the presence of a deoxy sugar, characteristic of cardiac glycosides. A violet ring may appear below the ring while in the acetic acid layer; a greenish ring may form just above ring and gradually spread throughout this layer.

\subsubsection{Test for reducing sugars}

One millilitre each of Fehling's solutions I and II was added to $2 \mathrm{ml}$ of the aqueous solution of the extract. The mixture was heated in a boiling water bath for about 2-5 minutes. The production of a brick red precipitate indicated the presence of reducing sugars.

\subsubsection{Fractionation of crude methanolic extract}

The crude extract was successfully partitioned using organic solvents in order of their polarity, that is, n-hexane, chloroform, diethyl ether and butanol. Exactly $90 \mathrm{~g}$ of the crude extract was resolved in $100 \mathrm{ml}$ of sterile distilled water in a $500 \mathrm{ml}$ separatory funnel. This was allowed to dissolve properly and later about $100 \mathrm{ml}$ of $\mathrm{n}$-hexane was added to the mixture for the extraction. The funnel was shaken vigorously and allowed to stand for $15 \mathrm{~min}$ to enable separation of the organic solvent and aqueous layer. The n-hexane fraction was thereafter separated from the aqueous layer and collected in a clean flask. The extraction was done thrice until the layer became colourless. The n-hexane fractions collected were bulked and concentrated to dryness in vacuo using rotary evaporator. The n-hexane fraction was coded $\mathbf{H F}$ and was kept in the freezer for further use. The aqueous layer left was re-concentrated in vacuo to eliminate residual $\mathrm{n}$-hexane. The same procedure described above was performed sequentially with the remaining solvents of chloroform (CF), diethyl ether (DEF), and butanol (BF).

\subsubsection{Accelerated Gradient Chromatography of active fractions of the extract}

The antimicrobially active diethyl ether 
fraction (DEF) and butanol fraction (BF) were separately dissolved in $50 \mathrm{ml}$ methanol, absorbed on silica gel $230-400$ mesh and evaporated to dryness in a rotary evaporator. They were separately chromatographed on a silica gel column $(650 \diamond 40 \mathrm{~mm})$ and gradiently eluted with a solvent system made from hexane, chloroform, methanol and ethyl acetate. The elution was started with nhexane only and later continued with Chloroform/n-hexane (10:90), Chloroform/ ethyl acetate (90:10), and finally Ethyl acetate/methanol $(90: 10)$, to obtain the diethy ether fraction $\mathbf{D E F}_{\mathbf{a}}$ and $\mathbf{D E F}_{\mathbf{b}}$. For the butanol fraction, Chloroform was first used to elute the fraction and later followed by Chloroform/ethyl acetate (90:10), and finally ethyl acetate/ methanol (90:10). The elutes collected in test tubes were bulked, based on similarity shown on TLC plates, developed in a suitable solvent system and visualized under the UV-light at 254 and 366 $\mathrm{nm}$. The plates were also sprayed with vanillin-sulphuric acid for colour development. The bulked fractions were concentrated to dryness in vacuo on a rotary evaporator and coded DEFa and DEFb for fractions collected from DEF. Fractions collected from $\mathbf{B F}$ were coded $\mathbf{B F a}$ and $\mathbf{B F b .}$

\subsubsection{Antibacterial activity assay}

The antibiograms of the partitioned fractions HF, CF, DEF and BF were determined using the agar-well diffusion method as described by Irobi et al. (1994) and Russell and Furr (1977) with modifications. The bacterial isolates were first grown in nutrient broth for $18 \mathrm{~h}$ before use. Two hundred microliters of the broth culture was used to inoculate $20 \mathrm{ml}$ of molten Mueller-Hinton agar (Oxoid) at 50 ${ }^{\circ} \mathrm{C}$ and then poured onto sterile Petri dishes and allowed to set. Wells were then bored into the agar medium using a sterile $6 \mathrm{~mm}$ cork borer. The wells were filled with the extract fractions, taking care to avoid spillage on the surface of the medium. Controls were set up in parallel using the solvents that were used to reconstitute the extract. The plates were allowed to stand on the laboratory bench for between 1-2 $h$ to allow proper diffusion of the fractions into the medium before incubating the plates at $37^{\circ} \mathrm{C}$ for $24 \mathrm{~h}$. The plates were later observed for the zones of inhibition. The effects of the extract on the test bacteria were compared to those of the standard antibiotics, streptomycin and tetracycline at a concentration of $1 \mathrm{mg} / \mathrm{ml}$ each.

\subsubsection{Determination of Minimum inhibitory concentrations (MIC)}

The MICs of the active fractions of the extract were determined using the description of Akinpelu and Kolawole (2004). Two-fold dilutions of the plant extract were prepared and $2 \mathrm{ml}$ of different concentration of the solution were added to $18 \mathrm{ml}$ of pre-sterilized molten nutrient agar at a temperature of $40^{\circ} \mathrm{C}$ to a series of concentrations of between 10 and 0.040 $\mathrm{mg} / \mathrm{ml}$. The media were then poured into sterile Petri dishes and allowed to set. The surfaces of the media were allowed to dry before streaking with $18 \mathrm{~h}$ old cultures of the susceptible test bacteria. The plates were later incubated in an incubator at 37 ${ }^{\circ} \mathrm{C}$ for up to $72 \mathrm{~h}$ after which they were examined for the presence or absence of growth. The MIC was taken as the lowest concentration that prevented bacterial growth.

\subsubsection{Determination of Minimum bactericidal concentrations (MBCs)}

The MBC of the active fractions of the extract were determined as described by Olorundare et al. (1992) with modifications. Samples were taken from plates with no visible growth in the MIC assay and subcultured onto freshly prepared nutrient agar medium and later incubated at $37^{\circ} \mathrm{C}$ for $48 \mathrm{~h}$. The MBC was taken as the lowest concentration of the extract that completely inhibited bacterial growth.

\subsubsection{Determination of the rate of killing and protein leakage}

Assay for the rate of killing of representative test bacteria by the active fractions was determined in accordance with the method of Odenholt et al. (2001). One representative 
each of Gram positive and Gram negative bacterial isolates were used viz., Bacillus anthracis (Gram positive) and Escherichia coli (Gram negative). The turbidity of an 18 $\mathrm{h}$ old broth culture of the test organism was standardized to approximately $10^{8} \mathrm{cfu} / \mathrm{ml}$. A $0.5 \mathrm{ml}$ volume of the standardized suspension was added to $4.5 \mathrm{ml}$ of different concentrations of the fractions. These were held at room temperature and the killing rate was determined over a period of $2 \mathrm{~h}$. Exactly $0.5 \mathrm{ml}$ volume of each suspension was withdrawn at time intervals and transferred to $4.5 \mathrm{ml}$ of nutrient broth recovery medium containing 3\% "Tween 80 " to neutralize the effects of the antimicrobial compound carryovers from the test organisms. The suspension was then serially diluted and plated out for viable counts. The plates were later incubated at $37^{\circ} \mathrm{C}$ for $48 \mathrm{~h}$. The control plates contained the bacterial cells without the extract. The emergent bacterial colonies were counted and compared with the counts of the culture control. Protein leakage was determined in accordance with the method in our previous description (Aiyegoro et al., 2008) by treatment of various concentrations of the extracts (relative to MIC) with bacterial cells washed three times in physiological saline by centrifugation at $10,000 \mathrm{rpm}$ for $10 \mathrm{~min}$ followed by resuspension in physiological saline. At intervals, each suspension was centrifuged at $7000 \mathrm{rpm}$ and the supernatant obtained was assayed for protein using the Bradford method (1976). The concentration of protein was estimated from the established standard curve obtained using bovine serum albumin (BSA). Bacillus anthracis (Gram positive) and Escherichia coli (Gram negative) were also used for this assay.

\subsection{RESULTS}

The results of our investigations showed that the crude methanolic extract of Garcinia kola along with the two partially purified fractions (DEFa and BFa) exhibited antimicrobial activities against some of the test bacterial isolates. The two solvents diethyl ether and butanol, which served as controls did not show any appreciable antimicrobial activity. The crude extract exhibited antimicrobial activity at a test concentration of $20 \mathrm{mg} / \mathrm{ml}$ while the two partially purified fractions exhibited activities at a lower concentration of $10 \mathrm{mg} /$ $\mathrm{ml}$ (Tables 1 and 2). The lowest zone of inhibition exhibited by the crude methanolic extract of $G$. kola was $10 \mathrm{~mm}$ while the highest zone of inhibition was $23 \mathrm{~mm}$ against $E$. coli. On the other hand, fraction DEFa exhibited the highest zone of inhibition of $22 \mathrm{~mm}$ against $B$. stearothermophilus, Corynebacterium pyogenes, and M. luteus. The lowest zone of inhibition exhibited by this fraction DEFa was $10 \mathrm{~mm}$ against $B$. cereus. The highest zone of inhibition exhibited by fraction $\mathbf{B F a}$ was $25 \mathrm{~mm}$ against $B$. anthracis, while the lowest zone of inhibition was $12 \mathrm{~mm}$ shown against Enterococcus faecalis. Fractions HF and $\mathbf{C F}$ did not inhibit the growth of any of the test bacteria. The two standard antibiotics, streptomycin and tetracycline used in this work exhibited zones of inhibition of $18 \mathrm{~mm}$ to $30 \mathrm{~mm}$ and $10 \mathrm{~mm}$ to $28 \mathrm{~mm}$ respectively.

The minimum inhibitory concentrations (MIC) of the fractions DEFa and BFa obtained from the crude extract of G. kola seeds along with that of streptomycin were also determined. The MIC of fraction DEFa varied between 0.313 and $5.0 \mathrm{mg} / \mathrm{ml}$, while that of BFa varied between 0.157 and 5.0 $\mathrm{mg} / \mathrm{ml}$, and that of streptomycin was between 0.0157 and $0.125 \mathrm{mg} / \mathrm{ml}$. The results indicated that streptomycin has stronger antimicrobial activity than the two fractions as indicated in Table 3.

Different concentrations of $\mathbf{B F a}$ fraction exhibited significant bactericidal effects on $E$. coli and $B$. anthracis over a period of time ranging between 15-120 mins. At a concentration of $1.25 \mathrm{mg} / \mathrm{ml}$ the BFa fraction killed about $19 \%$ of $E$. coli cells within $30 \mathrm{~min}$ and the proportion of cells killed with time continue to increase with concentration of the extract to attain peak values of between $57 \%$ and $100 \%$ in $2 \mathrm{hr}$ (Figure 1a). A similar trend of killing rate was observed for Bacillus anthracis (Figure 1b). The DEFa fraction also exerted bactericidal effect on the test organisms. For this fraction, between $42 \%$ and $100 \%$ 
TABLE 1

Sensitivity patterns of some bacterial isolates to crude methanolic extract of Garcinia kola seeds

\begin{tabular}{|c|c|c|c|}
\hline \multirow[t]{2}{*}{ Microorganism } & \multicolumn{3}{|c|}{ Zone of Inhibition $\left(\mathrm{mm}^{*}\right)$} \\
\hline & $\begin{array}{l}\text { G. kola extract } \\
(20 \mathrm{mg} / \mathrm{ml})\end{array}$ & $\begin{array}{l}\text { Streptomycin } \\
\quad(1 \mathrm{mg} / \mathrm{ml})\end{array}$ & $\begin{array}{c}\text { Tetracycline } \\
(1 \mathrm{mg} / \mathrm{ml})\end{array}$ \\
\hline Bacillus anthracis (LIO) & 18 & 18 & 25 \\
\hline Bacillus cereus (NCIB 6349) & Nil & 22 & 18 \\
\hline Bacillus stearothermophilus (NCIB 8222) & 20 & 23 & 22 \\
\hline Bacillus polymyxa (LIO) & 22 & 18 & 20 \\
\hline Bacillus subtilis (NCIB 3610) & 20 & 23 & 22 \\
\hline Clostridium sporogenes (NCIB 532) & 21 & 25 & 20 \\
\hline Corynebacterium pyogenes (LIO) & 10 & 20 & 20 \\
\hline Enterococcus faecalis (NCIB 775) & 10 & 23 & 28 \\
\hline Escherichia coli (NCIB 86) & 23 & Nil & 18 \\
\hline Klebsiella pneumoniae (NCIB 418) & 22 & Nil & 12 \\
\hline Micrococcus luteus (NCIB 196) & 13 & 18 & 22 \\
\hline Pseudomonas aeruginosa (NCIB 950) & Nil & Nil & Nil \\
\hline Pseudomonas fluorescens (NCIB 3756) & Nil & 30 & Nil \\
\hline Staphylococcus aureus (NCIB 8588) & Nil & 21 & Nil \\
\hline Staphylococcus epidermidis (LIO) & 10 & 21 & 10 \\
\hline
\end{tabular}

Key: NCIB $=$ National Collection of Industrial Bacteria; LIO = Locally isolated organisms; $\mathrm{mm}^{*}=$ Mean of three replicates.

TABLE 2

Sensitivity pattern of some bacterial isolates to various fractions of Garcinia kola seeds

\begin{tabular}{|c|c|c|c|c|c|c|c|c|c|c|}
\hline \multirow[t]{2}{*}{ Microorganism } & \multicolumn{10}{|c|}{ Zone of inhibition (mm*) } \\
\hline & $\mathrm{BF}$ & DEF & $\mathrm{HF}$ & $\mathrm{CF}$ & $\mathrm{BC}$ & $\mathrm{DC}$ & $\mathrm{HC}$ & $\mathrm{CC}$ & STR & TET \\
\hline Bacillus anthracis (LIO) & 25 & 22 & 0 & 0 & 0 & 0 & 0 & 0 & 18 & 25 \\
\hline Bacillus cereus (NCIB 6349) & 14 & 10 & 0 & 0 & 0 & 0 & 0 & 0 & 22 & 18 \\
\hline B. stearothermophilus (NCIB 8222) & 22 & 18 & 0 & 0 & 5 & 0 & 0 & 0 & 23 & 22 \\
\hline Bacillus polymyxa (LIO) & 15 & 20 & 0 & 0 & 0 & 5 & 0 & 0 & 18 & 20 \\
\hline Bacillus subtilis (NCIB 3610) & 20 & 20 & 0 & 0 & 5 & 5 & 0 & 0 & 23 & 22 \\
\hline Clostridium sporogenes (NCIB 532) & 0 & 0 & 0 & 0 & 0 & 0 & 0 & 0 & 25 & 20 \\
\hline Corynebacterium pyogenes (LIO) & 22 & 16 & 0 & 0 & 0 & 0 & 0 & 0 & 20 & 20 \\
\hline Enterococcus faecalis (NCIB 775) & 12 & 0 & 0 & 0 & 0 & 0 & 0 & 0 & 23 & 28 \\
\hline Escherichia coli (NCIB 86) & 21 & 18 & 0 & 0 & 0 & 0 & 0 & 0 & 0 & 18 \\
\hline Klebsiella pneumoniae (NCIB 418) & 16 & 16 & 0 & 0 & 0 & 0 & 0 & 0 & 0 & 12 \\
\hline Micrococcus luteus (NCIB 196) & 22 & 16 & 10 & 10 & 5 & 0 & 0 & 0 & 18 & 22 \\
\hline Pseudomonas aeruginosa (NCIB 950) & 0 & 14 & 0 & 0 & 0 & 0 & 0 & 0 & 0 & 0 \\
\hline Ps.fluorescens (NCIB 3756) & 17 & 0 & 0 & 0 & 0 & 0 & 0 & 0 & 30 & 0 \\
\hline Staphylococcus aureus (NCIB 8588) & 0 & 0 & 0 & 0 & 0 & 0 & 0 & 0 & 21 & 0 \\
\hline Staphylococcus epidermidis (LIO) & 0 & 0 & 0 & 0 & 0 & 0 & 0 & 0 & 21 & 10 \\
\hline
\end{tabular}

Key: NCIB = National Collection of Industrial Bacteria; LIO = Locally Isolated organisms; 0 = Not sensitive; $\mathrm{mm}^{*}=$ Mean of three replicates; DEF = Diethyl-ether Fraction $(10 \mathrm{mg} / \mathrm{ml}) ; \mathrm{BF}=$ Butanol Fraction $(10 \mathrm{mg} /$ $\mathrm{ml}) ; \mathrm{HF}=$ Hexane Fraction $(10 \mathrm{mg} / \mathrm{ml}) ; \mathrm{CF}=$ Chloroform Fraction $(10 \mathrm{mg} / \mathrm{ml}) ; \mathrm{BC}=\mathrm{Butanol} \mathrm{control} ; \mathrm{DC}=$ diethyl ether control; $\mathrm{HC}=$ hexane control; $\mathrm{CC}=$ chloroform control; STR = Streptomycin $(1 \mathrm{mg} / \mathrm{ml}) ; \mathrm{TET}=$ Tetracycline $(1 \mathrm{mg} / \mathrm{ml})$. 
TABLE 3

The minimum inhibitory concentrations (MIC) of active partially purified fractions and streptomycin

\begin{tabular}{lccc}
\hline Microorganism & \multicolumn{3}{c}{ Fractions } \\
\cline { 2 - 4 } & $\begin{array}{c}\mathrm{DEFa} \\
(10 \mathrm{mg} / \mathrm{ml})\end{array}$ & $\begin{array}{c}\mathrm{BFa} \\
(10 \mathrm{mg} / \mathrm{ml})\end{array}$ & $\begin{array}{c}\text { Streptomycin } \\
(1 \mathrm{mg} / \mathrm{ml})\end{array}$ \\
\hline Bacillus anthracis (LIO) & 0.313 & 0.157 & 0.125 \\
Bacillus cereus (NCIB 6349) & 5.0 & 2.5 & 0.0625 \\
Bacillus stearothermophilus (NCIB 8222) & 0.625 & 0.313 & 0.0313 \\
Bacillus polymyxa (LIO) & 1.25 & 2.5 & 0.125 \\
Bacillus subtilis (NCIB 3610) & 0.625 & 0.313 & 0.125 \\
Clostridium sporogenes (NCIB 532) & $\mathrm{ND}$ & $\mathrm{ND}$ & 0.0313 \\
Corynebacterium pyogenes (LIO) & 1.25 & 0.313 & 0.125 \\
Enterococcus faecalis (NCIB 775) & $\mathrm{ND}$ & 5.0 & 0.0313 \\
Escherichia coli (NCIB 86) & 1.25 & 1.25 & $\mathrm{ND}$ \\
Klebsiella pneumoniae (NCIB 418) & 1.25 & 0.313 & $\mathrm{ND}$ \\
Micrococcus luteus (NCIB 196) & 1.25 & $\mathrm{ND}$ & 0.125 \\
Pseudomonas aeruginosa (NCIB 950) & $\mathrm{ND}$ & 1.25 & $\mathrm{ND}$ \\
Pseudomonas fluorescens (NCIB 3756) & 2.5 & $\mathrm{ND}$ & 0.0157 \\
Staphylococcus aureus (NCIB 8588) & $\mathrm{ND}$ & $\mathrm{ND}$ & 0.0625 \\
Staphylococcus epidermidis (LIO) & $\mathrm{ND}$ & & 0.0625 \\
\hline
\end{tabular}

Key: DEFa $=$ Diethyl-ether Fraction; BFa $=$ Butanol Fraction; ND $=$ Not Done.

of the E. coli cells were killed within $2 \mathrm{hr}$, with the proportion of killed cells increasing with extract concentration (Figure 1c). As well, the proportion of cells of $B$. anthracis killed ranged from $32 \%$ for the lowest extract concentration of 0.652 $\mathrm{mg} / \mathrm{ml}$ to $100 \%$ for the highest extract concentration of $5 \mathrm{mg} / \mathrm{ml}$ (Figure 1d).

Both BFa and DEFa fractions caused considerable leakage of proteins from the cells of $E$. coli and B. anthracis. When $B$. anthracis cells were exposed to $\mathbf{B F a}$ fraction, between $8 \mu \mathrm{g} / \mathrm{ml}$ and $58 \mu \mathrm{g} / \mathrm{ml}$ protein were leaked from the cells in approximately $3 \mathrm{hr}$ with the concentration of leaked protein increasing proportional to the concentrations of the BFa (Figure 2a). With $E$. coli cells, protein leaked within the same period ranged from $20 \mu \mathrm{g} / \mathrm{ml}$ to about $80 \mu \mathrm{g} / \mathrm{ml}$ (Figure 2b).

\subsection{DISCUSSION}

The antimicrobial activity of $G$. kola seeds extract successfully inhibited the growth of both Gram-positive and Gram-negative organisms used in this study, thus, exhibiting a broad spectrum of activity. Fractions $\mathbf{H F}$ and $\mathbf{C F}$ used in our investigations did not exhibit antimicrobial activities against the tested isolates, unlike DEFa and Bfa, which were active. This observation might be attributed to the fact that the active constituents of G. kola seeds are either moderately polar or polar in nature, since only polar solvent fractions of the extract were observed to be active. This might serve as a pointer to the type of organic solvent that can be used in extracting active ingredients of this plant. In addition, using the MIC values, there was a good comparism between BFa fraction and the standard antibiotics used in this study (Table 3). On the other hand, BFa fraction showed better activities than DEFa fraction. This might be attributed to the higher polarity of butanol and thus more affinity for the active components of $G$. kola than diethyl ether.

Overall, the G. kola extract compared favourably with the two standard 
antibiotics. From this study, G. kola extract inhibited the growth of some of the pathogens tested and these include E. coli known to cause diarrhoea and urinary tract infections, as well as Kleb. pneumoniae, which is known to cause pneumonia and Bacillus polymyxa, the causative agent of bacterial seedling blight of tomato. These abilities of the plant extract to inhibit or kill these pathogens at minimal contact time and low concentration could be used in preventing the establishment of infections by these pathogens, thus supporting the use of $G$. kola seeds for the treatment of the diseases caused by these pathogens.

Protein leakage from the $B$. anthracis and $E$. coli cells on exposure to different concentrations of fractions BFa and DEFa followed a classical monophasic effects. Oloke (1989) reported a similar observation for a different plant, Aframomum melegueta. The monophasic effect is the increase in leakage with increases in concentrations of the fractions. The DEFa (a)

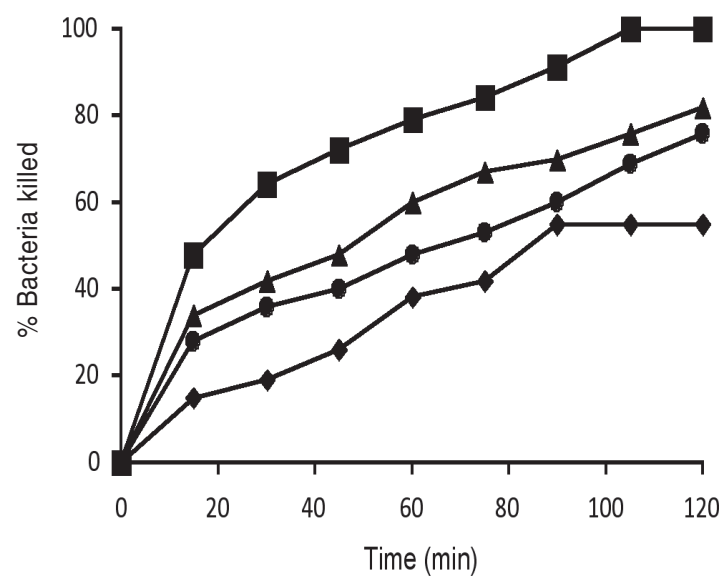

$\neg 0.625 \mathrm{mg} / \mathrm{ml} \rightarrow-1.25 \mathrm{mg} / \mathrm{ml} \longrightarrow 2.5 \mathrm{mg} / \mathrm{ml} \longrightarrow-5.00 \mathrm{mg} / \mathrm{ml}$

(c)

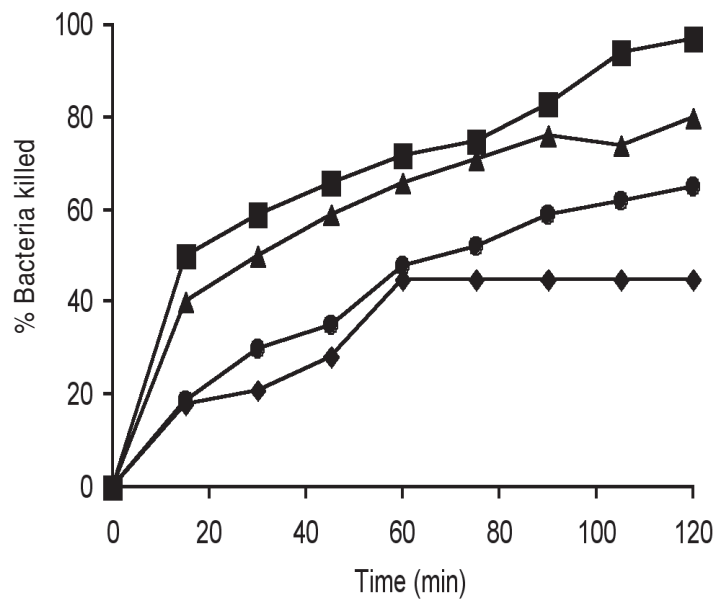

$\multimap 0.625 \mathrm{mg} / \mathrm{ml} \longrightarrow-1.25 \mathrm{mg} / \mathrm{ml} \longrightarrow 2.5 \mathrm{mg} / \mathrm{ml}$ (b)

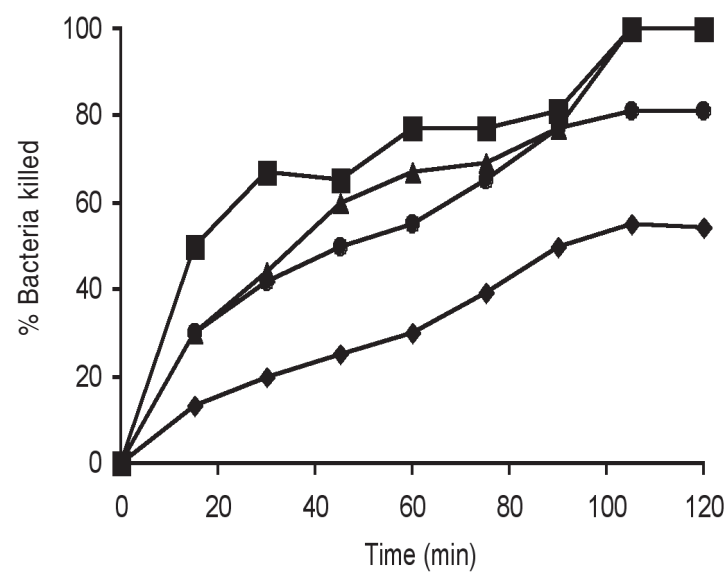

$\neg 0.625 \mathrm{mg} / \mathrm{ml} \rightarrow-1.25 \mathrm{mg} / \mathrm{ml} \longrightarrow 2.5 \mathrm{mg} / \mathrm{ml} \longrightarrow 5.00 \mathrm{mg} / \mathrm{ml}$

(d)

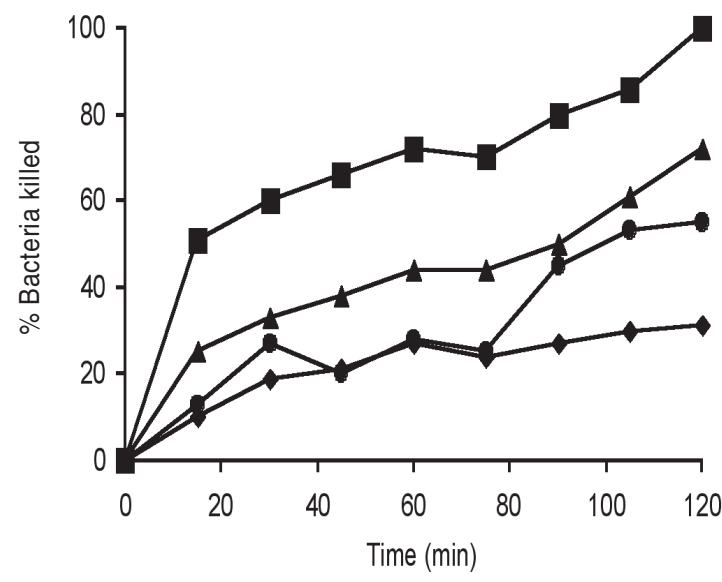

$\longrightarrow 0.625 \mathrm{mg} / \mathrm{ml} \rightarrow-1.25 \mathrm{mg} / \mathrm{ml} \longrightarrow 2.5 \mathrm{mg} / \mathrm{ml} \longrightarrow 5.00 \mathrm{mg} / \mathrm{ml}$

Figure 1: Profiles of rate of killing of Escherichia coli by BFa fraction (a); Bacillus anthracis by BFa fraction (b) fraction; Escherichia coli by DEFa fraction (c); and Bacillus anthracis by DEFa fraction (d) of Garcinia kola seeds. 
fraction showed similar activities when the two test organisms were subjected to the effect of the fraction. With longer duration of exposure of these cells to the effect of DEFa, cell viability decreased with a more significant increase in protein leakage (Figure 2b). Thus, when susceptible bacteria are exposed to antimicrobial agents this results in the leakage of intracellular materials because of the damage caused in the membrane of such cells. Previous workers (Slamenova et al. (2002) and Aherne et al. (2007) have reported leakage of intracellular materials from some cells. Aherne et al. (2007) investigated the effect of phytochemical compounds in inducement of stress in test organisms leading to the disruption of the cell membrane and thus causing leakage of cellular materials, including proteins. The fraction DEFa and BFa used in this study were found to cause leakage in protein, which led to the cell death, as shown in Figures $2 \mathrm{a}$ and $\mathrm{b}$. The leakage caused by the two fractions of $G$. kola extract is probably similar to that observed by these authors, thus suggesting cell membrane disruption and a probable mechanism of action of our DEFa and BFa extracts, more so with the presence of tannins in the extract, which have been

(a)

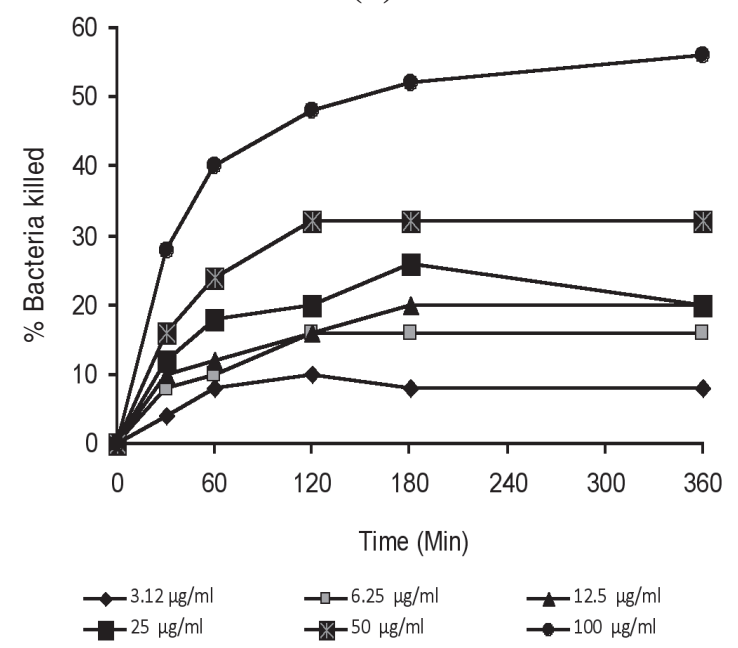

known to disrupt cell membranes (Scalbert, 1991).

The bactericidal activities of the fractions of $G$. kola were determined using viability studies. As the concentration of the fractions increased, the microbial population decreased as indicated in Figures 1a-d. There appears to be a relationship between the amount of cell constituents released and the number of organisms killed. For example, when the cells of $E$. coli were exposed to $1.25 \mathrm{mg} / \mathrm{ml}$ of the BFa fraction, about $19 \%$ of the E. coli cells were killed (Figure 1a). During the same time interval, $8 \%$ of the leakage of protein was caused by the BFa fraction (Figure 2b). Our investigations thus suggest that membrane components are the primary target of these two fractions (BFa and DEFa) of G. kola seed extract. With this action we concluded that disruption of the cell membrane by these fractions ultimately resulted in bacterial death as previously suggested by $\mathrm{Cao}$ et al. (2002). Hence, a probable mechanism of action of these fractions obtained from $G$. kola seed extract are by way of cell membrane disruption to $E$. coli and B. anthracis cells, although there might be other mechanism(s) of action exerted by these fractions that were not studied in our investigations.

Figure 2: The effect of partially purified BFa fraction of Garcinia kola on protein leakage in Bacillus anthracis (LIO) (a) and DEFa fraction of Garcinia kola on protein leakage in E. coli (NCIB 86) (b). 
The phytochemical analysis of the extract of $G$. kola revealed the presence of flavonoids, tannins, cardiac glycoside, steroids, saponins and reducing sugars. These phytochemical compounds are known to play important roles in bioactivity of medicinal plants. The medicinal values of medicinal plants lie in these phytochemical compounds, and as such, produce definite physiological actions on the human body. Flavonoids, which are part of the phytochemical constituents of $G$. kola, exhibit a wide range of biological activities, one of which is their ability to scavenge for hydroxyl radicals, and superoxide anion radicals, and thus health promoting in action (Ferguson, 2001). Flavonoids also exhibit anti-inflammatory, anti-angionic, anti-allergic effects, analgesic and antioxidant properties (Hodek et al., 2002). These observations support the usefulness of $G$. kola in folklore remedies for the treatment of various infections. Cardiac glycosides are an important class of naturally occurring drugs whose actions helps in the treatment of congestive heart failure (Ikeda et al., 1995). This compound has been reported to be a novel cancer therapeutic agent (Newman et al., 2008). Cardiac glycoside was present in $G$. kola extract, and this plant is used for the treatment of cardiac infections, along with other ailments, such as cough and chest pain among Yoruba tribe of southwestern Nigeria. Another phytochemical compound observed to be present in G. kola seeds extract is tannins. Tannins exert antimicrobial activities by iron deprivation, hydrogen binding or specific interactions with vital proteins, such as enzymes in microbial cells (Scalbert, 1991). Herbs that have tannins are astringent in nature and are used for the treatment of intestinal disorders, such as diarrhoea and dysentery (Dharmananda, 2003), and further supports why G. kola is among the medicinal plants used for the treatment of microbial infections. Tannins have been observed to have remarkable activity in cancer prevention ( $\mathrm{Li}$ et al., 2003). In addition to this, Motal et al. (1985) showed tannins to be useful in treatment of inflamed or ulcerated tissues. Thus, the presence of tannins in $G$. kola supports the traditional medicinal use of this plant in the treatment of ailments caused by microorganisms. Just et al. (1998) revealed inhibitory effect of saponins on inflamed cells. Saponin was also present in G. kola seed extract and has supported the usefulness of this plant in managing inflammation. Steroidal compounds also present in $G$. kola extract are of importance and interest in pharmacy due to their relationship with such compounds as sex hormones (Okwu, 2001). We conclude that Garcinia kola seeds could be a potential source of active antimicrobial agents, and a detailed assessment of their in vivo potencies is the subject of current extensive investigation by our group.

\section{ACKNOWLEDGEMENT}

We are grateful to the National Research Foundation (NRF) of South Africa and the Govan Mbeki Research and Development Centre (GMRDC) of the University of Fort Hare, Alice, South Africa for financial support.

\section{REFERENCES}

ADESINA $S \mathrm{~K}$, GBILE $\mathrm{Z}$ O, ODUKOYA $\mathrm{O} A$, AKINWUSI D D, ILLOH $\mathrm{H} \mathrm{C}$ and JAYEOLA A A 1995 Survey of indigenous useful plants of West Africa with special emphasis on medicinal plants and issues associated with management. The United Nations Programme on Natural Resources in Africa; $2^{\text {nd }}$ edition, pp. 84-85

AHERNE S A, KERRY J P and O'BRIEN N M 2007 Effects of plant extracts on antioxidant status and oxidant-induced stress in Caco-2 cells; Brit. J. Nutri., 97 321-328

AIYEGORO O A, AKINPELU D A, AFOLAYAN A J and OKOH A I 2008 Antibacterial activities of crude stem bark extracts of Distemonanthus benthamianus Baill; J. Biol. Sci., 8(2) 356-361

AJEBESONE P E and AINA J O 2004 Potential African Substances for Hops in Tropical Beer Brewing; J. Fd. Tech. Africa, 9(1) 13-16

AKINPELU D A and KOLAWOLE D O 2004 Phytochemistry and antimicrobial activity of leaf extract of Piliostigma thonningii (Schum); Science Focus, 7 64-70

AKOACHERE J F, NDIP R N, CHENWI E B, NDIP L M NJOCK T E and ANONG D N 2002 Antibacterial effect of Zingiber officinale and Garcinia kola on respiratory tract pathogens; East Afr. Med. J., 79 (11) 588-592

AYENSU E S 1978 Medicinal Plants of West Africa, Reference Publ. Inc., Algonac, Michigan. p.162 
BRADFORD M M 1976 A rapid and sensitive method for quantitation of microgram quatities of protein utilizing the principle of protein-dye binding; Analytical Biochemistry, 72 248-254

CAO M T, WANG R and HELMANN J D 2002 Antibiotics that inhibit cell wall biosynthesis induce expression of the Bacillus subtilis $\mathrm{W}$ and $\mathrm{M}$ regulons; Mol. Microbiol., 45(5) 1267-1276

DALZIEL J M 1937 The Useful Plants of West Tropical Africa. Crown Agents for the Colonies, London

DHARMANANDA S 2003 Gallnuts and the uses of Tannins in Chinese medicine. In; Proceedings of Institutes for Traditional Medicine, Portland, Oregon

EZEIFEKA G O, ORJI M U, MBATA T I and PATRICK A O 2004 Antimicrobial activity of Cajanas cajan, Garcinia kola and Xylopia aethiopica on pathogenic microorganisms; Biotech., 3(1) 41-43

FAROMBI EO, AKANNI OO, EMEROLE GO 2002 Antioxidant and scavenging activities of flavonoid extract (kolaviron) of Garcinia kola seeds. Pharmaceutical Biology 40(2):107-116

FERGUSON L R 2001 Role of plant polyphenols in genomic stability; Mutat. Res. 475 89-111

HAN Q B, LEE S F, QIAO C F, HE Z D, SONG J Z, SUN $\mathrm{H}$ D and XU H X 2005 Complete NMR Assignments of the Antibacterial Biflavonoid GB1 from Garcinia kola; Chem. Pharm. Bull., 53(8) 1034-1036

HARBOURNE J B 1983 Phytochemical Methods: A Guide to Modern Technique of plants Analysis. Chapman and Hall, London

HODEK P, TREFIL $P$ and STIBOROVA M 2002 Flavonoids-potent and versatile biologically active compounds interacting with cytochrome P450; Chemico-Biological Interactions, 139 1-21

IGWE C U, NWAOGU L A and UJUWANDU C O 2007 Assessment of the hepatic effects, phytochemical and proximate composition of Phyllanthus amarus; Afr. J. Biotech., 6 728-731

IKEDA Y, FUJII Y, NAKAYA I and YAMAZAK M 1995 Quntitative HPLC analysis of cardiac glycosides in Digitalis purpurea leaves; J. Nat. Prod. 58(60), 897901

IWU M M 1993 Handbook of African medicinal Plants. Boca Raton: CRC Press Inc. pp 223-224

IROBI O N, MOO-YOUNG M and ANDERSON W A 1994 Antimicrobial activity of Annato (Bixa orellana) extract; Int. J. Pharmacog., 34 87-90

JUST M J, RECIO M C, GINER R M, CUÉLLAR M J, MANEZ S, BILIA A R and RIOS J L 1998 Antiinflammatory activity of unusual lupine saponins from Bupleurum fruticescens; Planta Medica, 64 404-407

KIEM S and SCHENTAG J J 2006 Relationship of Minimal Inhibitory Concentration and Bactericidal Activity to Efficacy of Antibiotics for Treatment of Ventilator-Associated Pneumonia; Semin Respir Crit. Care Med., 27 51-67
LI H, WANG Z and LIU Y 2003 Review in the studies on tannins activity of cancer prevention and anticancer; Zhong-Yao-Cai 26(6) 444-448

MOTAL M L R, THOMAS G and FILLO B J M 1985 Effects of Anarcardium occidentale stem bark extract on in vivo inflammatory models; J. Ethnopharmacology 95(2-3) 139-142

NDUKWE K C, OKEKE I N, LAMIKANRA A, ADESINA S K and ABODERIN O 2005 Antibacterial Activity of Aqueous Extracts of Selected Chewing Sticks; J. Contemp. Dent. Pract., 3(6) 086-094

ODENHOLT I, LOWDIN E and CARS O 2001 Pharmacodynamics of telithromycin in vitro against respiratory tract pathogens; Antimicrob. Agents Chemother., 45(1) 23-29

OKWU D E 2001 Evaluation of the chemical composition of medicinal plants belonging to Euphorbiaceae; Pak. Ve.t J., 14 160-162

OLOKE J K 1989 The antimbacteria and antifungal effect of the volatile oil and partially purified extract of Aframomum melegueta K. Schum. A Ph.D. Thesis submitted to the Department of Microbiology University of Ife, Ile Ife, Nigeria

OLORUNDARE E E, EMUDIANUGHE T S, KHASAR G S, KOTEYI S A and IROBI D N 1992 Antibacterial properties of leave extract of Cassia alata; Bio. Res. Com., 4 113-117

RABE T and VAN STADEN J 1997 Antibacterial activity of South African plants used for medicinal purposes; J. Ethnopharmacol., 56 81-87

NEWMAN R A, YANG P, PAWLUS A D and BLOCK K I 2008 Cardiac glycosides as novel cancer therapeutic agents; Mol. Inv. 8 36-49

RUSSELL A D and FURR J R 1977 The antibacterial activity of a new chloroxylenolpreparation containing ethylenediamine tetraacetic acid; J. Appl. Bacteriol., 43 253

SCALBERT A 1991 Antimicrobial properties of tannins; Phytochemistry $303875-3883$

SLAMENOVA D, KUBOSKOVA K, HORVATHOVA E and ROBICHOVA S 2002 Rosemary-stimulated reduction of DNA strand breaks and FPG-sensitive sites in mammalian cells treated with $\mathrm{H} 2 \mathrm{O} 2$ or visible light-excited methylene blue; Cancer Lett., 177 145153

SIBANDA $\mathrm{T}$ and $\mathrm{OKOH}$ AI 2008a In vitro Antibacterial Regimes of Crude Aqueous and Acetone Extract of Garcinia kola Seeds; J. Biol. Sci. 8(1) 149-154

SIBANDA $\mathrm{T}$ and $\mathrm{OKOH}$ AI $2008 \mathrm{~b}$ In vitro evaluation of the interactions between acetone extracts of Garcinia kola seeds and some antibiotics; Afr. J. Biotech. 7(11) 1672-1678

TREASE G E and EVANS WC 1983 Pharmacognosy. 14 ${ }^{\text {th }}$ Edt, Publ. Brown Publ.Uko O J, Usman A and Ataja AM 2001 Some biological activities of Garcinia kola in growing rats; Veterinarski ARHIV 71(5) 287-297. 